Purwo Hadi Sukmana, Iman Harynawan: Peranan Gaya Kepemimpinan

\title{
PERANAN GAYA KEPEMIMPINAN TERHADAP KINERJA MANAJERIAL DEN- GAN VARIABEL MODERASI SISTEM AKUNTANSI MANAJEMEN, STRATEGI BISNIS DAN KETIDAKPASTIAN LINGKUNGAN
}

\author{
Purwo Hadi Sukmana \\ Universitas Airlangga \\ purwohadi.sukmana@gmail.com \\ Iman Harymawan \\ Universitas Airlangga \\ harymawan.iman@feb.unair.ac.id
}

\begin{abstract}
ABSTRAK
Kesuksesan pemimpin dapat dilihat dari kemampuan seorang pemimpin bisa menjadi pemicu yang dipimpinnya dengan menciptakan kondisi kerja yang kondusif sehingga mampu meningkatkan kemajuan serta peningkatan kemampuan dimana menghasilkan pengaruh positif bagi sumber daya manusia yang dipimpin dalam menjalan pekerjaan sesuai arah dalam pencapain tujuan organisasi. Penelitian ini menggunakan variabel moderasi sistem akuntansi manajemen, strategi bisnis dan ketidakpastian lingkungan yang dapat mendorong gaya kepemimpinan terhadap kinerja manajerial yang optimal.

Penelitian ini menggunakan hyphotheses testing study dengan metode pengumpulan data melalui kuesioner yang dibagikan pada responden manajer pada distributor farmasi yang tersebar di Sidoarjo dan Surabaya. Penelitian ini menghasilkan bahwa gaya kepemimpinan berpengaruh signifikan terhadap kinerja manajerial, namun untuk interaksi variabel (moderasi) dari strategi bisnis, sistem akuntansi manajemen dan ketidakpastian lingkungan tidak memberikan efek moderasi pada hubungan gaya kepemimpinan terhadap kinerja manajerial. Hal ini disebabkan karena distributor farmasi merupakan suatu instansi yang telah memiliki strategi bisnis dan sistem akuntansi manajemen yang optimal. Ketidakpastian lingkungan pada perusahaan yang bergerak di sektor ini juga tidak memberikan dampak yang signifikan bagikeberlangsungan organisasi, karena kebutuhan medis baik itu obatobatan ataupun alat kesehatan merupakan kebutuhan utama bagi unit kesehatan dan masyarakat Indonesia tentunya.
\end{abstract}

Kata kunci: gaya kepemimpinan, strategi bisnis, sistem akuntansi manajemen, ketidakpastian lingkungan, kinerja manajerial 


\section{LATAR BELAKANG}

Pergerakan bidang farmasi mulai bertumbuh pesat sejak pemerintah Indonesia pada tahun 1967 dan 1968 mengeluarkan Peraturan Perundang - undangan Penanaman Modal Asing (PMA) dan Penanaman Modal Dalam Negeri (PMDN).

Pesatnya pertumbuhan ini tidak lepas dari potensi pasar yang dimiliki oleh Indonesia dengan jumlah penduduk yang besar yang menjadi magnet kuat bagi banyak pelaku bisnis. BPS (Badan Pusat Statistik) menginformasikan laju peningkatan produktfitas tahun 2016 maengalami lonjakan pada industri manufaktur besar dan kecil. Industri farmasi termasuk dalam kelompok utama yang menyumbang kenaikan tersebut yang mengalami kenaikan sebesar 8,01 persen.

Perusahaan farmasi dituntut dalam memenuhi strategi bisnis yang dapat mendukung ekspansi yang agresif dan efisiensi biaya yang dilakukan perusahaan agar dapat menopang pertumbuhan laba dalam jangka menengah. Strategi tersebut perlu diperhitungkan oleh beberapa perusahaan farmasi dalam rangka mendukung rencana pemerintah yang akan meningkatkan penetrasi sistem Jaminan Kesehatan Nasional (JKN) hingga 100\% bagi seluruh penduduk Indonesia pada 2019 mendatang. Kebijakan tersebut dinilai bakal mendorong peningkatan permintaan pasar terhadap obat generik tak bermerek. Disamping itu, pada program JKN, resep obat bagi peserta JKN didominasi oleh obat generik tanpa merek dibandingkan dengan obat paten.

Tentunya, kondisi tersebut sungguh tidak menguntungkan perusahaan karena marjin obat generik relatif lebih rendah dibandingkan obat-obatan jenis lainnya. Perusahaan bidang farmasi berpusat menelaah, menumbuhkan dan menyalurkan obat kesehatan untuk masyarakat luas. Sharabati et al (2010) mengatakan perindustrian farmasi menjunjung modal intelektual. Perindustrian bidang farmasi cenderung melaksanakan pengkajian, inovasi dan selaras dalam memaksimal SDM (Sumber Daya Manusia) serta fasilitas teknologi. Perombakan produk keberlangsungan hidup perusahaan farmasi tersebut diperlukan.

Perombakan produk tergantung pada fondasi kepengetahuan perusahaan. Fenomena yang membuat produsen (pemasok) dan distributor perlu meninjau ulang kembali kinerja manajerialnya. 
Purwo Hadi Sukmana, Iman Harynawan: Peranan Gaya Kepemimpinan

Pengukuran manajerial yang baik dan dapat dipercayai secara mutlak untuk diperlukan dalam penilaian prestasi manajer dan unit organisasi yang berada di dalamnya pemimpinannya. Kinerja manajerial sebagai output rangkaian dari rantai aktivitas manajerial diawali dari merencanakan, melaksanakan, menata usahakan, melaporkan tanggung jawab, serta memonitor.

Mahoney (1965); Weihrich dan Koontz (1994) menyebutkan bahwa kinerja manajerial yaitu kinerja yang dilaksanakan dari manajer dalam menjalankan rutinitas manajerialnya seperti berencana, investigasi, monitoring dan mengatur staf serta bernegosiasi maupun mewakilkan. Pencapaian sumber daya manusia lebih baik tidak lepas adanya pengaruh yang diterima pemimpin dalam mengelola sumber daya manusia.

Tampi (2014) menjelaskan Gaya kepemimpinan merupakan tindakan yang dipilih dan dipergunakan oleh pemimpin yang mampu membuat pengaruh pada pikiran, perasaan, sikap, dan perilaku dalam beroganisasi.

Luthans (2002) dijelaskan cara leadership (Memimpin) sumber daya manusia yang ada sehingga dapat menjalankan sesuai kehendak perusahaan yang diinginkan. Perilaku dalam memimpin dari setiap pemimpin tidak sama sehingga dapat mempengaruhi akan keberhasilan dalam mengelolanya.

Kemampuan dalam memimpin yang baik dapat mengarahkan bawahannya untuk berkerja secara tepat dan jelas sehingga membuahkan inovasi dalam pekerjaan. Penelitian yang dilakukan Elenkov and Manev (2005) menjelaskan bahwa kepemimpinan dapat berpengaruh dalam pembentukan inovasi dalam pekerjaan yang bermanfaat bagi organisasi.

Penelitian gaya kepemimpinan telah banyak dilakukan terhadap kinerja di indonesia. Seperti yang telah dilakukan oleh Soegiono (2010) menemukan adanya interaksi pada kinerja manajerial. Trisnaningsih (2007) meneliti kinerja pada auditor tetapi mendapatkan hasil penelitiannya berpengaruh ke kinerja auditor. Akan tetapi pendapat lain, penelitian lain yang dilakukan oleh Vita (2015) mendapatkan hasil tidak menghasilkan pengaruh pada kinerja guru. Pendapat tersebut didukung oleh Gunawan dan Ramdan (2012) menemukan tidak terdapat kinerja auditor terpengaruh gaya kepemimpinan. Penelitian ditemukan hasil berbeda tersebut menyemangati meneliti kembali mengenai gaya kepemimpinan pada kinerja manajerial. 
Ihtiyath Vol. 2 No. 1 September 2018

Kinerja yang baik tidak lepas juga akan sistem memfasilitasi para manajer dalam kepemimpinannya maupun menjalankan operasional perusahaan yaitu SAM (sistem akuntansi manajemen). Menurut Mia (2008) dalam Chenhall dan Morris (1986) peran sistem akuntansi manajemen mengarahkan serta menyelesaikan polemik sebagai kendala organisasi sehingga menyebabkan kendala besar mengaplikasikan tersebut dibutuhkan data eksternal maupun internal non financial dengan penekanan terhadap memasarkan, terinovasinya produk, terencana yang baik maupun yang dapat dimanfaatkan pengambilan keputusan. Akan tetapi terdapat penelitian mendapatkan hasil bertolak belakang dari penjelasan penelitian yang terdahulu. Seperti yang ditemukan oleh Rahayu (2013) mendapatkan mendapatkan bahwa Sistem Akuntansi Manajemen tidak terpengaruh pada kinerja manajerial di perusahaan manufaktur yang ada pada kota padang. Penelitian yang mendapatkan hasil yang sama seperti yang dilakukan oleh Marina (2009) mendapatkan baik parsial maupun non parsial tidak berdampak pada kinerja manajerial. Hal tersebut disebabkan tercenderungnya penggunaan baik pada SAM (Sistem Akuntansi Manajemen) sehingga kinerja manajerial yang dihasilkan tidak akan selalu mengalami peningkatan.

Gelombang globalisasi dalam bisnis semakin meningkatkan dinamika dan intensitas persaingan yang mengakibatkan kondisi bersaing sehingga peran manajerial ditingkatkan dalam menentukan strategi bisnis perusahaan. Perubahan yang disebabkan bermacam situasi dalam lingkungan berbisnis berakibat strategi yang ditetapkan menjadi tidak relevan mensikapi kondisi lingkungan yang berubah memaksa organisasi berubah yang berdasar perangkaian strategi tersebut Courtney et al., (1997). Strategi diartikan sebagai perencanaan dalam menyikapi persaingan di lingkungan industri dimanan SBU (Strategy Business Unit) berada Robinson dan Pearce J (1997: 96). Anthony dan Govindarajan (2007) sebagai petunjuk umum yang terarahkannya rencana organisasi.

Konsep strategi bersaing menurut Porter (1985), mengingat strategy business unit (SBU) harus selalu memantau lingkungan eksternal dan internalnya sendiri serta memposisikan bisnisnya dalam industri untuk dapat terus bertahan atau bahkan berkembang maju menjadi pemimpin atau leader dalam industri yang persaingannya sangat ketat.

Dalam penelitian ini strategi bisnis diukur dengan melihat kecenderungan strategi bisnis mengarah pada cost leadership atau differentiation. 
Roswinda (2017) menjelaskan bahwa ketidakpastian yaitu ketidakpunyaan informasi dari para manajer yang memadai dalam memahami dan meramalkan kebutuhan dari faktor-faktor lingkungan untuk dapat mengikuti perubahan yang terjadi pada lingkungan. Lingkungan tidak pasti tinggi diartikan individu tidak sanggup memprediksi kejadian pada lingkungan. Sedangkan rendahnya lingkungan yang tidak pasti diartikan sebagai kemampuan individu dalam mengambil langkah perencanaan yang tepat untuk organisasi. Dari pernyataan tersebut, Ketidakpastian lingkungan antara hubungan gaya kepemimpinan terhadap manajerial telah banyak diteliti.

Penelitian yang telah dilakukan oleh Elenkov dan Manev (2005) menjelaskan bahwa Semakin besar pentingnya suatu kepemimpinan tidak terletak akan dampak langsung pada masalah substantif yang tidak terkendali dari luar organisasi melainkan kemampuan untuk memberikan kontrol terhadap makna dan interprestasi dari kejadian apapun dari lingkungan yang relevan untuk mempengaruhi kinerja.

Penelitian ketidakpastian lingkungan antara hubungan gaya kepemimpinan dan kinerja manajerial telah dilakukan oleh Meindhl dan Ehlrich (1985) menjelaskan kepercayaan berlebih dalam kepemimpinan akan cenderung membuat kontrol yang nyata dalam memperhitungkan varians yang tidak bisa dikendalikan seperti kondisi politik maupun sosial yang dapat menjaga aktivitas dari hal yang berpotensi mengganggu kinerja di dalam organisasi.

Pada penelitian ini akan menguji kembali dimodifikasikannya beberapa variabel diujikanya dalam moderator yaitu sistem akuntansi manajemen, strategi bisnis, dan ketidakpastian lingkungan untuk menggambarkan adanya interaksi atau tidaknya pada hubungan gaya kepemimpinan terhadap kinerja manajerial. Perusahaan distributor farmasi di wilayah Sidoarjo dan Surabaya akan dijadikan sebagai sampel karena peneliti dilakukan berawal dari bidang perusahaan yang sama untuk mengetahui variabel moderator tersebut berinteraksi atau tidaknya pada perusahaan distributor farmasi lainnya.

Tujuan dari penelitian yang dilakukan yaitu: a) Memperoleh bukti ilmiah tentang pengaruh gaya kepemimpinan terhadap kinerja manajerial, b) Memperoleh bukti ilmiah tentang strategi bisnis memperkuat interaksi gaya kepemimpinan berpengaruh terhadap kinerja manajerial, c) Memperoleh bukti ilmiah tentang sistem akuntansi manajemen memperkuat interaksi gaya kepemimpinan berpengaruh terhadap kinerja manajerial, d) 
Ihtiyath Vol. 2 No. 1 September 2018

Memperoleh bukti ilmiah tentang ketidakpastian lingkungan memperkuat interaksi gaya kepemimpinan berpengaruh terhadap kinerja manajerial.

\section{LITERATURE AND HYPOTHESIS}

Gaya Kepemimpinan

Pernyataan Rokhman et al. (2011) yakni aktivitas mengajak, memotivasi tindakan bawahan, mengajak perbaikan atas tim yang dipimpinnya ke arah yang telah ditentukan. Hasibuan (2007:170) sebagai pemikiran mengajak bawahan untuk saling membantu secara produktif kearah penentuan tujuan.

Leaderhsip (Kepemimpinan) sebagai aktivitas atau seni personal yang berpengaruh sosialisme dalam menggunakan wewenangnya, menyemangati kepada orang yang satu dengan orang lain untuk saling membantu pekerjaan didalam direktorat atau divisi Terry (1998); Markow dan Klenke (2005); DuBrin A (2005)

\section{Strategi Bisnis}

Porter (1985) menyatakan kinerja superior berawal dari kehandalan strategik. Jermias and Gani (2005) menjelaskan strategi keunggulan bersaing dalam memperoleh kinerja perusahaan didukung data dari SAM (Sistem Akuntansi Manajemen).

\section{Ketidakpastian Lingkungan}

Milliken (1987) berkata kebutuhan akan informasi berbeda tergantung pada kemauan manager satu sama lainnya. Ketidakpastian lingkungan kemampuan terbatasnya seseorang manager akan merencanakan situasi yang terjadi di luar aktivitas perusahaan.

Duncan (1972) ketidakpastian lingkungan merupakan daya terbatasnya kemampuan individual di dalam penilaian probabilitas (Kemungkinan) kegagalan atau keberhasilan keputusan yang dibuat. Pernyataan Duncan (1972) dalam Mulyani (2012) menyimpulkan adanya kekosongannya informasi yang digunakan pada waktu mengambil tindakan tanpa mengetahui analisa sebab - sebab yang ada di lingkungan, ketidakpengetahuan output kerugian diambilnya tindakan terdampak ke perusahaan, dan ketidaksemangatan berpengaruhnya dalam tindakan yang diambil mengenai factors (faktor - faktor) 62 
lingkungan.

Ketidakpastian lingkungan adalah ketidakpengetahuan seseorang meramalkan kondisi lingkungannya Luthans (2002).

Child (1972) mendapatkan adanya dua dimensi ciri khas ketidakpastian lingkungan yaitu kompleksitas dan dinamika. Lingkungan yang kompleks diartikan pengambilan tindakan yang dihasilkan pemetaan dalam dikelolanya kondisi dibutuhkan kedalaman abstrak. Sedangkan lingkungan dinamika sebagai pengambilan suatu tindakan berubah konstan disebabkan didapatkan faktor (factor) yang terjadi bersamaan di saat pemilihan tindakan. Terbatasnya daya individu pada lingkungan beragam di saat telah dibuatnya tindakan apakah berdampak kegagalan ataupun keberhasilan berpengaruh tingkatan (kinerja) perusahaan Duncan (1972); Jensen and Meckling (1998).

\section{Sistem Akuntansi Manajemen}

Kegunaan dari sistem akuntansi manajemen (SAM) yaitu terinformasi keuangan di internal terorientasi historis saja akan tetapi pertambahan penggunaannya yang menyebabkan SAM berubah pada aktivitas manager. Tujuan umum SAM terangkum ada 3, yaitu :

(1) tersedianya informasi yang bermanfaat perhitungan HPP (Harga Pokok Penjualan), (2) ketersediaannya informasi yang bermanfaat membantu perencanaan, pengendalian, dan perbaikan berkelanjutan, dan

(3) tersedianya informasi meenjadi acuan pemilihan keputusan.

Chenhall and Morris (1986), mengidentifikasi empat karakteristik informasi SAM yaitu sebagai berikut:

\section{a. Broadscope (Ruang Lingkup)}

Gordon dan Narayan (1984) menyatakan dipusatkan pada dimensi focus, kuantifikasi dan horizon waktu. Gambaran data Lingkupan SAM (Sistem Akuntansi Manajemen) terhubung lingkungan eksternal yang ekonomi pendapatan kotor produk, kondisi angka penjualan dan pangsa pasar industri maupun juga bersifat non ekonomi seperti demografi, keseleraan konsumen, action dari para pesaing dan kemajuan teknologi. 
Timeliness (Ketepatan Waktu)

Timeliness (Ketepatan waktu) mempengaruhi kapabilitas para manajer menanggapi kondisi yang terjadi. Timeliness (ketepatan waktu) sebagai data pemberitahuan dalam memilih keputusan atas pelaporan pada peristiwa yang akhir berkejadian. Pelaporan dan kecepatan pelaporan adalah inti dari Timeliness SAM.

b. Level of Agregation (Aggregasi),

Pemberian menginformasi dari pemberian bahan dasar maupun data tidak terproses berdasarkan jarak waktu atau kejadian tertentu yaitu pusat pertanggungjawaban.

Aggregasi informasi menggabungkan temporal dan fungsional data.

c. Integration (Integrasi)

Pengkoordinasian bermacam segmen dalam direktorat-direktorat pada organisasi. Integrasi (Integrasion) SAM mencakup detail target yang berpengaruh dalam tindakan sub unit per divisi.

\section{Kinerja manajerial}

Mulyadi (2001) menyatakan gambaran pencapaian level (tingkatan) aktivitas yang terlaksana. Kinerja dimaksudkan pencapaian perusahaan dalam jangka waktu yang dtinjau dari pelaksanaan aktivitas yang terjadwal sesuai kebijakan berlandaskan terwujudnya tujuan dan misi perusahaan tercantum pada perencanaan strategik.

Kinerja sebagai pencapaian seseorang dalam dikerjakannya penugasan yang dbebani kepadanya didasarkan atas kecakapan (skills), pengalaman (historical work), kesungguhan (intent) bekerja serta waktu (time). Kinerja manajerial sebagai tercapainya realisasi kerja personal (seseorang) dalam Activity Managerial (Aktivitas Manajerial) yaitu planning, Investigation (investigasi), Interaction (interaksi), evaluation, Monitoring, staffing, negotiation, dan representation. Pengukuran kinerja manajerial pengembangan penelitian Mahoney et al. (1965) yang menjelaskan managerial performance (kinerja manajerial dipengaruhi beberapa factor (faktor), antara lain:

Faktor Pribadi yaitu skills (keahlian), kepercayaan diri (over confident), motivation (motivasi) dan komitmen (commitment),

Faktor Kepemimpinan (leadership factor) yaitu semangat, pedoman pemberian semangat manajer dan pemimpin divisi maupun perusahaan,

Faktor Tim/kelompok yaitu sistem pekerjaan dan fasilitas yang tersedia, Faktor Situasion64 
Purwo Hadi Sukmana, Iman Harynawan: Peranan Gaya Kepemimpinan

al) yaitu perubahan dan tekanan lingkungan dalam maupun luar.

\section{Research Hypothesis}

Transformasional leadership (kepemimpinan transformasional) mendorong untuk lebih berinovatif dalam strategi differensi produk organisasi kepada pelanggan Elenkov and Manev (2005).

Mulyadi (2001) menjelaskan penilaian kinerja penentuan secara periodik efektivitas yang dikerjakan pada perusahaan didasarkan tujuan yang ditetapkan sebelumnya. Penelitian ini didasari oleh penelitian Su-chao chang dan Ming-Shing Lee (2007) dan Tampi (2014) yang menemukan hasil bahwa gaya kepemimpinan pada suatu perusahaan akan berpengaruh terhadap kinerja manaerial perusahaan, hal ini berkaitan dengan sifat, kebiasaan, tempramen, watak dan kepribadian yang membedakan seorang pemimpin dalam berinteraksi dengan orang lain. Berdasarkan hasil penelitian dan kajian literatur empiris diatas diajukan hipotesis sebagai berikut :

\section{$\mathbf{H}_{1}=$ Gaya kepemimpinan berpengaruh terhadap kinerja manajerial}

Strategi bisnis sangat dibutuhkan perusahaan dalam menghadapi persaingan global. Peran strategi ditingkatkan dari kepengetahuan organisasi dalam bertahan yang disebabkan hempasan globalisasi berakibat dinamika dan intensitas persaingan Howell dan Avolio 1993. Kinerja manajerial mengukur capaian pelaksanaan fungsi manajerial. Fungsi manajemen ini tidak terlepas dari gaya kepemimpinan yang dijalankan oleh level manajerial. Pemimpin puncak mempunyai keefektifan apabila mereka melakukan perubahan yang inovasi pada strategi dalam organisasi.

Penelitian mengenai strategi bisnis sebagai variabel moderasi sangat sedikit oleh peneliti sebelumnya. Penelitian Chenhall dan Morris (1986) serta Jermias dan Gani (2005) yang hanya mengujikan pengaruh langsung terhadap kinerja manajerial, dan ditemukan bahwa terdapat pengaruh antara strategi bisnis terhadap kinerja manajerial. Strategi bisnis dalam penelitian ini dijadikan sebagai variabel moderasi karena diduga dapat memperkuat gaya kepemimpinan dalam mempengaruhi kinerja manajerial. Strategi bisnis yang digunakan dalam penelitian ini adalah tipe defender dan tipe prospector. Penelitian ini ingin menguji apakah dengan dua tipe strategi bisnis tersebut dapat menjadi faktor memmperkuat gaya kepemimpinan seorang manajer dalam menentukan kepemimpinannya 
dan keputusan bisnis yang akan dipilih.

$\mathrm{H}_{2}=$ Strategi bisnis dapat memperkuat hubungan gaya kepemimpinan berpengaruh terhadap kinerja manajerial.

Benchmarking dan pengendalian yang terdapat dalam SAM yang dianggap penting bagi manajer untuk mencapai tujuan organisasi dan nilai tambah di mata pelanggan. Selain diharapkan memberikan pendekatan individu, gaya kepemimpinan dapat digunakan untuk melakukan pendekatan terhadap pelanggan. Dengan sistem Akuntansi manajemen dapat menghilangkan ketidakefektifan subunit dalam efektifitas operasi untuk mencapai kepuasan pelanggan Jermias dan Gani (2005).

Sistem akuntansi manajemen yang terintegrasi baik pada perusahaan dapat mendorong hubungan gaya kepemimpinan terhadap kinerja manajerial. Kualitas informasi dapat terjamin, apabila prosedur pengumpulan data dalam sistem pengukuran kinerja secara periodik telah diupdate dan ditelaah. Informasi kinerja yang baik akan mempermudahkan pembacanya untuk menilai pencapaian kinerja dari pelaksanaan program atau kegiatan. Penelitian mengenai strategi bisnis sebagai variabel moderasi sangat sedikit oleh peneliti sebelumnya. Penelitian Abernethy (2000) menemukan bahwa sistem akuntansi manajemen sangat bergantung pada strategi perusahaan yang telah ditetapkan sebelumnya. Penelitian ini tidak meneliti tentang moderasi sistem akuntansi manajemen dalam memoderasi gaya kepemimpinan. Sedangkan penelitian Setiawan (2012) menemukan bahwa sistem akuntansi manajemen berpengaruh terhadap kinerja manajerial.

\section{$\mathrm{H}_{3}=$ Sistem akuntansi manajemen dapat memperkuat hubungan gaya kepemimpinan berpengaruh terhadap kinerja manajerial.}

Lingkungan organisasi bisa mempengaruhi kinerja organisasi Lieberson and O'Connor (1972). gaya kepemimpinan merupakan pola tingkah laku yang digunakan manajer mengajak bawahannya dalam pencapaian tujuan organisasi.

Penelitian mengenai ketidakpastian lingkungan sebagai variabel moderasi sangat sedikit oleh peneliti sebelumnya. Penelitian Setiawan (2012) menemukan bahwa ketidakpastian lingkungan tidak memoderasi hubungan antara broadscope terhadap kinerja manajerial, dan ketidakpastian lingkungan memoderasi hubungan antara aggregation terhadap kinerja manajerial. Penelitian ini diperkuat dengan penelitian Chenhall dan Morris (1986) yang menemukan bahwa dampak dari ketidakpastian lingkungan yang dirasakan dapat 66 
Purwo Hadi Sukmana, Iman Harynawan: Peranan Gaya Kepemimpinan

merubah kebijakan perusahaan dalam menjawab ketidakpastian lingkungan tersbut. $\mathbf{H}_{4}=$ Ketidakpastian lingkungan dapat memperkuat hubungan gaya kepemimpinan berpengaruh terhadap kinerja manajerial

\section{METHODOLOGY}

Desain Penelitian: Reserach (penelitian) bertujuan untuk menguji empat buah hipotesis yaitu hipotesis yang menguji pengaruh gaya kepemimpinan terhadap kinerja manaerial yang dimoderasi dengan sistem akuntansi manajemen, strategi bisnis, ketidakpastian lingkungan yang dipersepsikan sehingga penelitian ini merupakan hypotheses testing study. Hypotheses testing study biasanya penetapan pembeda diantara dua kelompok independen atau lebih dalam sebuah situasi (Sekaran, 2006). Penelitian ini menggunakan moderated regression analysis (MRA) dengan tujuan untuk mengetahu arah dan atau kekuatan hubungan antara variabel independen dengan variabel dependen. Penelitian ini menggunakan variabel moderasi strategi bisnis, sistem akuntansi manajemen dan ketidakpastian lingkungan. Data primer dilaksanakan dalam research terkumpul berbagai jalan yaitu terkirim secara langsung ke sampel yang dimaksud. Quetionnare (kuesioner) terdiri atas pertanyaan tertutup dan optional dengan ditambahkan pertanyaan reverse (R). Distributor farmasi yang berada di wilayah Sidoarjo dan Surabaya diambil sebagai populate. Sedangkan sampel penelitian ini adalah perusahaan dengan kriteria sampel penelitian.

\section{Definisi dan Pengukuran Variabel} Gaya Kepemimpinan (X1)

Leadership (Kepemimpinan) merupakan kecakapan untuk mempengaruhi suatu kelompok kearah tercapainya suatu tujuan. Penggunaan indikator pertanyaan yang diambil dari Oades et al. (2009) berfokus pada gaya kepemimpinan transformasional. Setiap butir item pertanyaan dalam kuisioner diukur menggunakan Skala Likert dengan jenjang penilaian yang mana poin terendah 1 dan poin tertinggi 5 . Adapun indikator pertanyaan adalah: a) Kekuatan, kepercayaaan dan etika, b) Nilai, c) kepercayaan dan misi dalam organisasi, d) mengedepankan apa yang terpenting, f) berpikir positif tentang masa depan, g) kepedulian terhadap bawahan ,kebanggan dalam tim kerja misi kolektif dan $\mathrm{h}$ ) Antusiasme Sistem. 


\section{Sistem Akuntansi Manajemen (z1)}

Terdapat 4 (empat) ciri khas teradopsi dari Chenhall dan Morris (1986) yaitu broad scope, ketepatan waktu, agregasi, dan integrasi.

\section{Strategi Bisnis (z2)}

Penggunaan Instrumen yang digunakan dari De Jong et al (1998) dengan adanya penggunaan penilaian tersendiri dari strategi yang digunakan dalam bisnis perusahaan tempat pengisi bekerja. Peneliti mengganti istilah defender menjadi tipe A dan prospector manjadi tipe B dalam lembar kuesioner yang dibagikan ke penjawab.

\section{Ketidakpastian Lingkungan (z3)}

Variabel ketidakpastian lingkungan yang dipersepsikan dari Chong (1998) terdapat tujuh butir pertanyaan dirancang dalam mengukur penanggapan pengisi dapat diperkirakan dan stabilitas pada perusahaan responden.

\section{Kinerja Manajerial (Y)}

Penggunaan kembali alat uji dari Mahoney et al. (1965) berupa penilaian pada diri sendiri yaitu tanya jawabnya peserta kearah nilai melebihi sebenarnya berbanding pengukuran kinerja ketika staff dinilai atasan (superior-rating. Peralatan uji penilaian diri sendiri digunakan Heneman (1974) tetap dipakai dalam penelitian ini karena beberapa alasan sebagai berikut:

a. Terhindari pengukuran performance yang tidak representatif digunakan superior-rating dimungkinkan adanya para supervisor tidak paham actual situation, b. Tercegahnya tinjauan kembali keumuman kinerja manajerial, c. Tersedianya 8 (delapan) sub ukuran performance dan tingkatan ke sembilan adalah keseluruhan. Kinerja dinilai turun disebabkan kebanyakan unsur digunakan, d. Research arah studi akuntansi manajemen menggunakan penilaian sendiri (self-rating)

Data analysis technique: Peneliti menggunakan Uji Validitas, Uji Reabilitas dan Uji Regresi (Normalitas, Heterokskedasitas, Uji auto korellasi). Peneliti dalam menguji variabel in68 
Purwo Hadi Sukmana, Iman Harynawan: Peranan Gaya Kepemimpinan

denpent maupun depend variabel modeasi (Uji t dan Koefisian Determinase (R2).

\section{RESULTS}

\section{Normality Test}

Anggapan dessain dikatakan terpenuhi yang dikatakan normal distribution melebihi 30 sampel sedangkan reseacrh ini telah menggunakan 130 data sampel penelitian, maka secara umum dapat disimpulkan telah memenuhi asumsi normalitas. Berikut adalah tabel output untuk uji normalitas:

\section{Tabel 1}

\section{Hasil Perhitungan Normalitas}

\begin{tabular}{|c|c|c|}
\hline $\begin{array}{c}\text { Mod- } \\
\text { el }\end{array}$ & $\begin{array}{c}\text { Nilai Kolmog- } \\
\text { orov-Smirnov } \\
\text { Z }\end{array}$ & $\begin{array}{c}\text { Nilai } \\
\text { Asymp. } \\
\text { Sig }\end{array}$ \\
\hline 1 & 2,083 & 0,000 \\
\hline 2 & 2,037 & 0,000 \\
\hline 3 & 1,672 & 0,007 \\
\hline 4 & 1,341 & 0,055 \\
\hline
\end{tabular}

Sumber: Hasil olah data SPSS 21.0 for Windows, 2018.

\section{Analysis Coefficient of Determination $\left(R^{2}\right)$}

Koefisiensi determinasi $\left(R^{2}\right)$ meninjau seberapa jauh mampunya dessain dalam menjelaskan dependent variable.

Coeficientt Value determinasi diantara o (nol) atau (1) satu.

Tabel 2

Koefisien Determinasi

\begin{tabular}{|c|c|}
\hline Model Penelitian & Hasil R-Square \\
\hline Model 1 & $0,926(92,6 \%)$ \\
\hline Model 2 & $0,927(92,7 \%)$ \\
\hline Model 3 & $0,963(96,3 \%)$ \\
\hline Model 4 & $0,956(95,6 \%)$ \\
\hline
\end{tabular}

Sumber: Lampiran, 2018. 
Ihtiyath Vol. 2 No. 1 September 2018

Berdasarkan hasil uji diatas dapat dilihat bahwa R-square dalam penelitian ini menunjukkan hasil 92,6\% untuk model 1, 92,7\% untuk model 2, 96,3\% untuk model 3 dan 95,6\% untuk model 4. Artinya adalah persentase tersebut mewakili besarnya pengaruh semua variabel independen terhadap variabel dependennya, sedangkan sisa persentase (100\% - nilai R-square) dipengaruhi oleh variabel independen yang bersifat non-fundamental yang tidak dapat di jelaskan dalam penelitian ini.

Hasil uji signifikansi tiap variabel dari setiap model penelitian ini dengan menjabarkan nilai signifikansi dari hasil regresi untuk setiap model penelitian.

\section{Table 3}

\begin{tabular}{|c|c|c|c|c|c|}
\hline Moded & Variabel & Koefuien & Nalait & Nalai Sug & Kesiapelan \\
\hline Model 1 & $\mathrm{GK}$ & 0,841 & $\$ 0,416$ & 0,000 & Hipotesis diterima \\
\hline \multirow[t]{3}{*}{ Modef 2} & GK & 0.853 & 32,401 & 0,000 & \\
\hline & 53 & 0.134 & 0,770 & $0 .+43$ & \\
\hline & CSBSB & $-0,027$ & $-0,600$ & 0.544 & Hrpotesis Detolak \\
\hline \multirow[t]{3}{*}{ Model 3} & GK & 0.068 & 0,065 & 0.508 & \\
\hline & SA24 & 0.816 & 9,948 & 0,000 & \\
\hline & CNSSAM & -0.001 & $-0,057$ & 0.947 & Hipoteiai Deolak \\
\hline \multirow[t]{3}{*}{ Made! 4} & CR: & 0,392 & 4,556 & 0,000 & \\
\hline & LNGK & 0,632 & 7,932 & 0,000 & \\
\hline & CXINCK & -0.025 & -1.620 & 0.108 & Hrpoteras Dtoolak \\
\hline
\end{tabular}

Berdasarkan hasil pengujian SPSS, berikut ini adalah pengujian hipotesisnya:

1. Gaya kepemimpinan (GK) berpengaruh terhadap kinerja manaerial, hal ini ditunjukkan oleh nilai signifikansi sebesar 0,000 yang artinya lebih kecil dari tingkat signifikansi 0,05, maka hipotesis diterima.

2. Interaksi antara gaya kepemimpinan (GK) dengan stratgei bisnis (SB) tidak berpengaruh terhadap kinerja manajerial, hal ini ditunjukkan oleh nilai signifikansi sebesar 0,544 yang artinya lebih besar dari tingkat signifikansi 0,05, maka hipotesis ditolak.

3. Interaksi antara gaya kepemimpinan (GK) dengan sistem akuntansi manajemen (SAM) tidak berpengaruh terhadap kinerja manajerial, hal ini ditunjukkan oleh nilai signifikansi sebesar 0,947 yang artinya lebih besar dari tingkat signifikansi 0,05, maka hipotesis ditolak.

4. Interaksi antara gaya kepemimpinan (GK) dengan ketidakpastian lingkungan (LINGK) tidak berpengaruh terhadap kinerja manajerial, hal ini ditunjukkan oleh nilai signifikansi sebesar 0,108 yang artinya lebih besar dari tingkat signifikansi 0,05, maka hipotesis ditolak. 


\section{PEMBAHASAN}

\section{Gaya Kepemimpinan Terhadap Kinerja Manajerial}

Model 1 penelitian ini mendapatkan bahwa gaya kepemimpinan berpengaruh signifikan terhadap kinerja manajerial, dengan nilai signifikansi sebesar 0,000 yang artinya lebih kecil dari tingkat signifikansi 0,05, maka hipotesis diterima.

Gaya kepemimpinan sangat erat kaitannya terhadap kemajuan organisasi. Apabila gaya kepemimpinan yang digunakan seorang manajer telah sesuai dan tepat bagi organisasinya, maka akan mendorong untuk lebih berinovatif dalam strategi differensi produk organisasi kepada pelanggan. Hal ini sesuai dengan penelitian Elenkov and Manev (2005) dan Howell and Avolio (1993) yang menyatakan bahwa gaya kepemimpinan transaksional mengaitkan prioritas, nilai-nilai dan asumsi yang berkaitan kesadaran diri perilaku yang dipimpin. Gaya kepemimpinan transaksional lebih mempertimbangkan pertimbangan individu, merangsang cara intelektual dan menghasilkan kepercayaan secara individu untuk mencapai keefektifan tujuan organisasi. Kinerja yang dinilai secara periodik, merupakan tolok ukur standard suatu organisasi, bagian organisasi dan karyawannya berdasarkan sasaran standar dan kriteria yang telah ditetapkan sebelumnya. Sebagai seorang manajer yang baik, maka seorang manajer harus dapat membuktikan kepada manajemen bahwa ia harus paham dengan informasi mengenai satuan kerja, program kegiatan melalui process, output dan outcome dalam mencapai kinerja seorang manajer yang optimal.

\section{Interaksi Strategi Bisnis Terhadap Hubungan Gaya Kepemimpinan Terhadap Kinerja Ma- najerial}

Model 2 penelitian ini mendapatkan bahwa Interaksi antara gaya kepemimpinan (GK) dengan stratgei bisnis (SB) tidak berpengaruh terhadap kinerja manaerial, hal ini ditunjukkan oleh nilai signifikansi sebesar 0,544 yang artinya lebih besar dari tingkat signifikansi 0,05, maka hipotesis ditolak.

Strategi bisnis dalam dunia distribusi farmasi dan obat-obatan di wilayah Sidoarjo dan Surabaya mengalami persaingan yang ketat. Namun hal ini tidak mendorong seorang manajer untuk menentukan sebuah strategi bisnis dengan shooting-point yang terlalu prospektif. Strategi bisnis yang digunakan oleh perusahaan distrusi farmasi ini menurut data penelitian memilih strategi defender, dimana berusaha untuk beroperasi dan memelihara bidang usaha yang aman dalam produknya yang relatif stabil karena bagi kon- 
Ihtiyath Vol. 2 No. 1 September 2018

sumen pengguna produk suatu farmasi akan memilih bekerjasama secara jangka panjang dengan distributor, untuk itu perusahaan tetap memberikan penawaran terbaik baik dari sisi harga dan pelayanan penjualannya.

Perusahaan farmasi cenderung untuk menawarkan jenis produk atau jasa yang lebih terbatas dibandingkan dengan kompetitornya, dan berusaha untuk memproteksi domainnya dengan menawarkan kualitas yang lebih tinggi, pelayanan yang lebih baik, harga yang lebih rendah dan lain-lain. Perusahaan dengan tipe ini bukan pelopor dalam pengembangan suatu industri tetapi cenderung untuk mengabaikan perusahaan industri yang tidak mempunyai pengaruh langsung dalam lingkup operasi dan konsentrasi perusahaan saat ini. Perusahaan lebih senang melakukan yang terbaik dalam lingkup area yang terbatas.

\section{Interaksi Sistem Akuntansi Manajemen Terhadap Hubungan Gaya Kepemimpinan Terh- adap Kinerja Manajerial}

Model 3 penelitian ini mendapatkan bahwa interaksi gaya kepemimpinan (GK) dengan sistem akuntansi manajemen (SAM) tidak berpengaruh terhadap kinerja manajerial, hal ini ditunjukkan oleh nilai signifikansi sebesar 0,947 yang artinya lebih besar dari tingkat signifikansi 0,05, maka hipotesis ditolak.

Informasi sistem akuntansi manajemen terdiri dari empat karakteristik yaitu broad scope, timeliness, agregasi, dan integrasi. Masing-masing dari karakteristik informasi sistem akuntansi manajemen pada perusahaan distribusi farmasi sudah jelas diatur dengan sistem yang terintegrasi. Salah satunya bukti penelitian menurut Chenhall dan Morris (1986), yang digunakan untuk mengukur persepsi informasi broad scope adalah indikator yang bermanfaat bagi para manajer. Ukuran kemanfaatan karakteristik informasi sistem akuntansi manajemen tidak memberikan hubungan antara sistem akuntansi manajemen dan kinerja. Alasan yang mendasari hal ini adalah bahwa persepsi terhadap informasi yang bermanfaat dari akuntansi manajemen, belum tentu menjamin bahwa informasi tersebut ada atau tersedia dalam perusahaan.

Oleh karena itu, penelitian ini memakai ukuran persepsi responden dalam mengakui ketersediaan informasi dari sistem akuntansi manajemen. Rata-rata perusahaan distribusi farmasi ini telah didukung dengan keberadaan canggihnya Software akuntansi untuk menyimpan semua data dan informasi penjualan. Software tersebut tentunya telah dilengkapi fitur-fitu canggih yang dapat menganalisa secara agregat dari sistem akuntan- 
si manajemen perusahaan itu sendiri.

\section{Interaksi Ketidakpastian Lingkungan Pada Hubungan Dan Gaya Kepemimpinan Terha- dap Kinerja Manajerial}

Model 4 menjelaskan bahwa interaksi antara gaya kepemimpinan (GK) dengan ketidakpastian lingkungan (LINGK) tidak berpengaruh terhadap kinerja manajerial, hal ini ditunjukkan oleh nilai signifikansi sebesar 0,108 yang artinya lebih besar dari tingkat signifikansi 0,05, maka hipotesis ditolak.

Penolakan hipotesis ini terjadi dikarenakan perusahaan distributor farmasi dan farmasi merupakan perusahaan yang menyalurkan obat-obatan farmasi ataupun alat-alat kesehatan baik untuk apotik, rumah sakit ataupun unit layanan kesehatan yang tentunya semua produk tersebut telah memiliki merek dan hak paten atas produk itu sendiri. Produk obatobatan dan alat kesehatan sangat tinggi permintaannya dikarenakan dibutuhkan untuk penyembuhan masyarakat. Menurut Sharabati et al (2010) perusahaan farmasi merupakan industri yang sangat memanfaatkan modal intelektual. Lebih lanjut Sharabati et al (2010) memandang bahwa industri farmasi merupakan industri yang intensif melakukan penelitian, industri yang inovatif dan seimbang dalam penggunaan sumber daya manusia serta teknologi. Pembaharuan produk dan inovasi sangat penting bagi keberlangsungan hidup perusahaan farmasi. Pembaharuan produk dan inovasi yang penting tersebut sangat bergantung pada modal intelektual yang dimiliki perusahaan. Jadi dapat disimpulkan bahwa perusahaan farmasi baik itu produsen ataupun distributor tidak akan berpengaruh dengan suatu ketidakpastian lingkungan karena merupakan kebutuhan utama bagi unit kesehatan dan masyarakat Indonesia tentunya.

\section{KESIMPULAN}

Berdasarkan hasil analisa dan pembahasan, maka simpulan atas penelitian ini adalah:

1. Gaya kepemimpinan (GK) berpengaruh terhadap kinerja manaerial.

2. Interaksi antara gaya kepemimpinan (GK) dengan stratgei bisnis (SB) tidak berpengaruh terhadap kinerja manajerial.

3. Interaksi antara gaya kepemimpinan (GK) dengan sistem akuntansi manajemen (SAM) tidak berpengaruh terhadap kinerja manajerial.

4. Interaksi antara gaya kepemimpinan (GK) dengan ketidakpastian lingkungan (LINGK) tidak berpengaruh terhadap kinerja manajerial.

Keterbatasan penelitian ini adalah: Variabel yang digunakan penelitian ini hanya terbatas 
Ihtiyath Vol. 2 No. 1 September 2018

pada gaya kepemimpinan (sebagai variabel independen), sedangkan digunakan variabel moderasi yaitu strategi bisnis, sistem akuntansi manajemen dan ketidakpastian lingkungan. Penelitian ini hanya terbatas menggunakan kinerja manajerial sebagai variabel dependen, Penentuan responden hanyalah wilayah Surabaya dan Sidoarjo. Penentuan target responden adalah manajer di perusahaan distrbutor farmasi dan alat-alat kesehatan.

Masukan dari karya ini adalah Untuk pengembangan variabel penelitian dapat digunakan variabel-variabel penelitian lainnya sebagai penentu kinerja manajerial, begitu juga dapat digunakan variabel independen dan variabel moderator lainnya agar dapat dihasilkan hasil penelitian yang lebih komprehensif lagi.

Untuk penentuan responden dapat digunakan wilayah yang lebih luas lagi, seperti wilayah Jawa Timur.

Untuk penentuan target responden, dapat dipilih responden selain manajer di perusahaan distrbutor farmasi dan alat-alat kesehatan, agar dapat mengembangkan wacana dan hasil penelitian ini.

\section{DAFTAR PUSTAKA}

Abernethy, J. B. a. M. A. 2000. Accounting, Organizations and Society. ScienceDirect, Volume 25(3), 221-241. doi: https://doi.org/10.1016/S0361-3682(99)00043-4

Anthony, R. N., Govindarajan, V., \& Dearden, J. 2007. Management control systems (Vol. 12): McGraw-Hill New York, NY.

Chang, S.-C., \& Lee, M.-S. 2007. A study on relationship among leadership, organizational culture, the operation of learning organization and employees' job satisfaction. The learning organization, 14(2), 155-185.

Chenhall, R. H., \& Morris, D. 1986. The impact of structure, environment, and interdependence on the perceived usefulness of management accounting systems. Accounting Review, 16-35.

Child, J. 1972. Organizational structure, environment and performance: The role of strategic choice. sociology, 6(1), 1-22.

Chong, V. K. 1998. Testing the Contingency 'Fit' Between Management Accounting Systems and Managerial Performance: A Research Note on the Moderating Role of 
Purwo Hadi Sukmana, Iman Harynawan: Peranan Gaya Kepemimpinan

Tolerance for Ambiguity". British Accounting Review, Vol. 30, No. 4, pp. 331 -342.

Courtney, H., Kirkland, J., \& Viguerie, P. 1997. Strategy under uncertainty. Harvard business review, 75(6), 67-79.

De Jong, T., Van Joolingen, W. R., Swaak, J., Veermans, K., Limbach, R., King, S., \& Gureghian, D. 1998. Self-directed learning in simulation-based discovery environments. Journal of Computer Assisted Learning, 14(3), 235-246.

DuBrin, A. J. 2005. Self-perceived technical orientation and attitudes toward being flattered. Psychological reports, 96(3), 852-854.

Duncan, R. B. 1972. Characteristics of organizational environments and perceived environmental uncertainty. Administrative science quarterly, 313-327.

Elenkov, D. S., \& Manev, I. M. 2005. Top management leadership and influence on innovation: The role of sociocultural context. Journal of management, 31(3), 381-402.

Gordon and Narayan, 1984, Management Accounting System, Perceired Environment Uncertainty and Structure: An Empirical Investigation, Accounting, Organization, and Society, p.33-47.

Gunawan, H., \& Ramdan, Z. 2012. Pengaruh Konflik Peran, Ketidakjelasan Peran, Kelebihan Peran, dan Gaya Kepemimpinan terhadap Kinerja Auditor Di Kantor Akuntan Publik Wilayah DKI Jakarta. Binus Business Review, 3(2), 825-839.

Hasibuan, M. S. 2007. Manajemen dasar, pengertian dan masalah. Jakarta: Bumi Aksara.

Heneman, H. G. 1974. Comparisons of self-and superior ratings of managerial performance. Journal of Applied Psychology, 59(5), 638.

Howell, J. M., \& Avolio, B. J. 1993. Transformational leadership, transactional leadership, locus of control, and support for innovation: Key predictors of consolidated-business-unit performance. Journal of applied psychology, 78(6), 891.

Jensen, M., \& Meckling, W. 1998. Divisional performance measurement.

Jermias, J., \& Gani, L. 2005. Ownership structure, contingent-fit, and business-unit performance: A research model and empirical evidence. The International Journal of Accounting, 40(1), 65-85.

Lieberson, S., \& O'Connor, J. F. 1972. Leadership and organizational performance: A study of large corporations. American sociological review, 117-130. 
Ihtiyath Vol. 2 No. 1 September 2018

Luthans, F. 2002. Positive organizational behavior: Developing and managing psychological strengths. Academy of Management Perspectives, 16(1), 57-72.

Mahoney, T. A., Jerdee, T. H., \& Carroll, S. J. 1965. The job (s) of management. Industrial Relations: A Journal of Economy and Society, 4(2), 97-110.

Marina, A. 2009. Pengaruh sistem akuntansi manajemen terhadap kinerja manajerial dengan ketidakpastian lingkungan dan desentralisasi sebagai variabel moderating. Universitas Muhammadiyah Surabaya.

Markow, F., \& Klenke, K. 2005. The effects of personal meaning and calling on organizational commitment: An empirical investigation of spiritual leadership. International Journal of Organizational Analysis, 13(1), 8-27.

Meindl, J. R., Ehrlich, S. B., \& Dukerich, J. M. 1985. The romance of leadership. Administrative science quarterly, 78-102.

Mia, L., \& Winata, L. 2008. Manufacturing strategy, broad scope MAS information and information and communication technology. The British Accounting Review, 40(2), 182-192.

Milliken, F. J. 1987. Three types of perceived uncertainty about the environment: State, effect, and response uncertainty. Academy of Management review, 12(1), 133-143.

Mulyadi, A. 2001. Akuntansi manajemen. Bandung: Program Studi Akuntansi UPI.

Mulyani, R. 2012. Pengaruh Komitmen Organisasi dan Ketidakpastian Lingkungan Terhadap Hubungan Antara Partisipasi Anggaran dengan Senjangan Anggaran (Studi Empiris pada Perusahaan Perbankan BUMN di Pekanbaru). Universitas Islam Negeri Sultan Syarif Kasim Riau.

Oades, L. G., Crowe, T. P., \& Nguyen, M. 2009. Leadership coaching transforming mental health systems from the inside out: The Collaborative Recovery Model as person-centred strengths based coaching psychology. International coaching psychology review, 4(1), 25-36.

Porter, M. E., \& Millar, V. E. 1985. How information gives you competitive advantage: Harvard Business Review Cambridge, MA.

Rahayu, M. 2013. Pengaruh Intensitas Informasi Akuntansi Manajemen Terhadap Kinerja Manajerial Dengan Ketidakpastian Lingkungan Sebagai Variabel Intervening (Studi Empiris Perusahaan Manufaktur di Kota Padang). Jurnal Akuntansi, 1(1). 
Purwo Hadi Sukmana, Iman Harynawan: Peranan Gaya Kepemimpinan

Robinson Jr, R. B., \& Pearce, J. A. 1983. The impact of formalized strategic planning on financial performance in small organizations. Strategic Management Journal, 4(3), 197-207.

Rokhman, W., Rivai, H. A., \& Adewale, A. 2011. An examination of the mediating effect of islamic work ethic on the relationships between transformational leadership and work outcomes. Gadjah Mada International Journal of Business, 13(2), 125-142.

Roswinda, W. 2017. Pengaruh Customization Strategy Terhadap Kinerja Perusahaan Melalui Penggunaan Karakteristik Sistem Informasi Akuntansi Manajemen (Studi Pada PT Bio Farma). Fakultas Ekonomi dan Bisnis Unpas Bandung.

Sekaran, Uma. 2006. Metode Penelitian Bisnis 2 Edisi 4. Jakarta: Salemba Empat.

Setiawan, A. S. 2012. Ketidakpastian Lingkungan Memoderasi Hubungan Antara Sistem Akuntansi Manajemen Terhadap Kinerja Manajerial (Studi Empiris Pada Perusahaan Perbankan di Kota Palembang) Jurnal Akuntansi, XVI No 01, 99-111.

Sharabati, A.-A. A., Naji Jawad, S., \& Bontis, N. 2010. Intellectual capital and business performance in the pharmaceutical sector of Jordan. Management decision, 48(1), 105-131.

Soegiono, P. 2010. Pengaruh Kepemimpinan, Tuntutan Tugas dan Karier Staknan terhadap Stres Kerja, dan Dampaknya bagi Komitmen Organisasi dan Organization Citizienship Behavior Karyawan PT Alfa Retailindo Surabaya. Jurnal Aplikasi Manajemen, 8(2), 446-454.

Tampi, B. J. 2014. Pengaruh Gaya Kepemimpinan dan Motivasi Terrhadap Kinerja Karyawan Pada Pt. Bank Negara Indonesia, Tbk (Regional Sales Manado). Jurnal Acta Diurna, 3(4).

Terry, L. D. 1998. Administrative leadership, neo-managerialism, and the public management movement. Public Administration Review, 194-200.

Trisnaningsih, S. 2007. Independensi auditor dan komitmen organisasi sebagai mediasi pengaruh pemahaman good governance, gaya kepemimpinan dan budaya organisasi terhadap kinerja auditor. SNA X Makassar.

Vita, B. 2015. Pengaruh Gaya Kepemimpinan, Budaya Organisasi, Dan Lingkungan Kerja Terhadap Kinerja Guru dan Karyawan pada Yayasan Tri Asih Jakarta. UAJY.

Weihrich, H., \& Koontz, H. 1994. Management: A global perspective. McGraw-Hill. 